\title{
PENERAPAN PRINSIP PEMBIAYAAN SYARIAH (MURABAHAH) PADA BMT BINA USAHA DI KABUPATEN SEMARANG
}

\author{
Lukman Haryoso \\ Jurusan Manajemen, Fakultas Ekonomi Universitas Islam Sultan Agung \\ 26Lukmanharyoso@std.unissula.ac.id
}

\begin{abstract}
Abstrak
$\mathrm{P}$ enelitian ini bertujuan untuk mengidentifikasi penerapan prinsip syariah yang dilakukan oleh BMT. Isu yang berkembang saat ini mengenai pembiayaan murabahah terutama yang dilakukan oleh bank yaitu menyimpang dari prinsip syariah. Penelitian ini menggunakan metode exploratory research, dengan melakukan wawancara untuk mendapatkan data dari nasabah BMT. Hasil penelitian ini menunjukan bahwa BMT dalam prakteknya sudah menerapkan prinsip syariah. Tapi BMT mengalami kesulitan dalam menerapkan pembiayaan yang lain, karena ada keraguan dan kesulitan dalam prakteknya.
\end{abstract}

Kata Kunci: Murabahah, Pembiayaan, Margin Dalam Murabahah, Prinsip Syariah

\begin{abstract}
$T$ his paper is aimed to identify the implementation of Islamic principle that has been doing by BMT. The current issue is about murabahah funding especially on sharia banking that deviate from Islamic principle. This research is using exploratory research methodolgy, by using interview to collect data from client of BMT. The research shows that BMT has implemented murabahah funding based on Islamic principle. But BMT has not implemented the others, because there are still some hesitancy and difficulties in practice.
\end{abstract}

Keywords: Murabahah, Funding, Margin Of Murabahah, Islamic Principle

\section{PENDAHULUAN}

Ajaran Islam mencangkup segala aspek kehidupan termasuk di dalamnya adalah aspek muamalah. Aspek muamalah ini digunakan untuk mengatur manusia dalam bersosialisasi, karena manusia secara hakikat adalah makhluk sosial. Muamalah merupakan istilah umum yang memberi makna dalam berbagai aktivitas, termasuk didalamnya mengenai kegiatan perniagaan, transaksi keuangan, perdagangan, dan yang paling sering manusia lakukan adalah kegiatan jual beli.

Kegiatan jual beli yang sering dilakukan merupakan upaya untuk memenuhi kebutuhan hidup manusia. Dalam kegiatan jual beli tentu harus dilakukan akad yang jelas, sebab apabila akad yang dilakukan tidak tepat maka jual beli yang terjadi tidak sah secara prinsip syariah. Tujuan jual beli yaitu untuk menjauhkan manusia dari praktik riba, karena riba merupakan hal yang di benci oleh Allah SWT dan harus dijauhi, sebab pelaku riba akan mendapatkan dosa besar. Dalam Al Qur'an surat Al-Baqarah: 275 dijelaskan:

"mengenai riba yaitu orang - orang yang makan (mengambil) riba tidak dapat berdiri melainkan seperti berdirinya orang yang kemasukan syaitan lantaran (tekanan) penyakit gila, keadaan mereka yang demikian itu adalah disebabkan mereka berkata,jual beli sama dengan riba, padahal Allah telah menghalalkan jual beli dan mengharamkan riba, orang - orang yang telah sampai padanya larangan dari tuhannya lalu terus berhenti (dari mengambil riba), maka baginya 
apa yang telah diambilnya dahulu (sebelum datang larangan) dan urusannya (terserah) kepada Allah, orang yang kembali (mengambil riba) maka orang itu adalah penghuni neraka, mereka kekal di dalamnya".

Selain itu dalam hadist Rasul disebutkan juga mengenai larangan keras terhadap praktik riba karena riba merupakan kegiatan yang zalim dari Abdullah bin Mas'ud r.a dari Nabi SAW beliau bersabda:

Dari Abu Hurairah $R$ A ia berkata : Rasululla bersabda :"Riba adalah tujuh puluh dosa, dosanya yang paling ringan adalah (sama dengan) dosa orang yang berzina dengan ibu kandungannya”. (HR.Muslim).

Perkembangan zaman saat ini menunjukan kemajuan dalam kegiatan ekonomi, banyaknya lembaga keuangan memberi kemudahan manusia untuk melakukan kegiatan perniagaan. Karena lembaga keuangan memberikan kemudahan akses bagi nasabahnya dalam mendapatkan pinjaman uang ntuk kebutuhan usaha dan kebutuhan barang pribadi yang kemudian nasabah membayar angsuran beserta bunga yang ditetapkan. Hal ini tentu tidak sepaham dengan pandangan Islam, karena bunga merupakan riba dan riba adalah perbuatan yang dibenci Allah SWT dan harus dihindari.

Munculnya lembaga keuangan syariah memberikan angin segar bagi umat Islam, khususnya di Indonesia. Diantaranya adalah badan usaha syariah, unit usaha syariah, bank pembiayaan rakyat syariah, dan Baitul mal waat tamwil atau BMT. Lembaga keuangan ini mengupayakan agar kegiatan transaksi keuangan bebas dari praktik riba dan memberi keamanan bagi umat manusia agar terhindar dari dosa besar.

Banyak isu bermunculan mengenai keberadaan lembaga keuangan syariah ini. Diantaranya adalah dari tiga jenis pembiayaan yang menjadi produk utama lembaga keuangan syariah yaitu pembiayaan mudharabah, pembiayaan musyarakah, dan pembiayaan murabahah, yang paling mendominasi yaitu pembiayaan murabahah. Pembiayaan dengan akad murabahah mencapai $56,8 \%$ dari total pembiayaan yang ada di perbankan syariah, sementara pembiayaan mudharabah dan musyarakah hanya $22,1 \%$ dan $14,1 \%$ dari total pembiayaan yang ada. Kemudian mengenai margin pada pembiayaan murabahah yang ditetapkan berdasarkan interestrate atau suku bunga yang ada di lembaga kuangan konvensional tidak pada kesepakatan bersama (Heykal, 2012). Menurut Mansuri (2006) murabahah merupakan kegiatan jual beli, dimana penjual menunjukan harga sesungguhnya yang dikeluarkan untuk mendapat produk tersebut serta menambahkan keuntungan yang didasarkan pada kesepakatan bersama. Murabahah dijadikan sebagai model pembiayaan dikarenakan lembaga keuangan syariah mengalami kesulitan dalam hal pembiayaan mudharabah dan musyarakah.

Dalam penelitian Haitam (2015) Ulama di Indonesia dari 10 provinsi mengatakan bank syariah di Indonesia belum murni menjalankan Syariat Islam. Praktek murabahah di Bank Islam juga jelas melanggar prinsip-prinsip syariah yang telah dijelaskan oleh Dewan Syariah Nasional MUI. Hal ini perlu diteliti juga terhadap praktek pembiayaan murabahah yang ada pada BMT.

Dari latar belakang masalah yang telah diuraikan diatas, maka dalam penelitian ini akan dilakukan penelitian lebih lanjut dengan pendekatan kualitatif untuk menganalisis bagaimana pelaksanaan pembiayaan murabahah pada BMT.

\section{KAJIAN PUSTAKA}

\section{Murabahah}

Telah menjadi pendapat dimuka umum bahwa pembiayaan murabahah keluar dari prinsip syariah,masyarakatmenyebutbahwamarginyangditetapkanpadapembiayaanmurabahahadalah sama dengan bunga bank. Banyak yang berpendapat bahwa bunga sama dengan riba, namun ada yang beranggapan bahwa bunga tidak sama dengan riba. Anggapan ini seketika membingungkan 
masyarakat, padahal riba merupakan dosa besar yang harus dihindari. Fatwa MUI (2000) Bunga (interest) adalah tambahan yang dikenakan dalam transaksi pinjaman uang yang diperhitungkan dari pokok pinjaman tanpa mempertimbangkan pemanfaatan pokok tersebut, berdasarkan tempo waktu, diperhitungkan secara pasti di muka, dan pada umumnya berdasarkan persentase. Riba adalah tambahan tanpa imbalan yang terjadi karena penangguhan dalam pembayaran yang diperjanjikan sebelumnya. Penyebab utamanya yaitu pengetahuan masyarakat yang rendah mengenai pembiayaan murabahah. Disisi lain murabahah tidak hanya digunakan untuk membiayai sektor konsumtif saja melainkan pembiayaan sektor produktif dengan sistem pemberian modal barang kepada pelaku usaha yang barang tersebut dijual kembali kepada konsumen. Padahal hal semacam ini dapat mempengaruhi keberlangsungan lembaga pembiayaan, karena kepercayaan masyarakat akan berkurang terhadap pembiayaan murabahah dan masyarakat mungkin akan kembali ke sistem kredit, padahal hal itu tidak dibenarkan. Sedangkan adanya pembiayaan murabahah itu adalah upaya untuk menghindari dosa besar yang disebabkan oleh adanya praktik riba.

Menurut Usmani (2002) Murabahah adalah penjualan dan pembelian yang meliputi penetapan harga dan ditambah dengan keuntungan yang disepakati oleh pihak penjual dan pembeli. Murabahah pada dasarnya yaitu penjualan yang berasakan pada kepercayaan, dimana pembeli tergantung dan bergantung pada kejujuran penjual dan penjual menyebutkan biaya sesungguhnya atas perolehan barang tersebut. Sedangkan menurut Haitam (2015) murabahah adalah sebuah pergeseran kepemilikan sesuatu yang dimiliki yang kemudian dijual dengan harga pertama lalu diberikan sedikit tambahan keuntungan.Dari seluruh definisi yang dinyatakan oleh beberapa sumber intinya adalah sama, bahwa murabahah adalah kegiatan jual beli dimana penjual menceritakan biaya perolehan barang yang sesungguhnya kepada pembeli lalu ditambahkan keuntungan atas penjualan tersebut berdasarkan biaya yang dikeluarkan dan kesepakatan antara penjual dan pembeli. Oleh karena itu seringkali salah presepsi mengenai penetapan margin murabahah menjadi hal yang kurang menguntungkan, karena tujuan jual beli yang baik bisa disalah artikan.

\section{Margin Dalam Murabahah}

Pendapat ahli hukum Islam menjelaskan mengenai biaya yang dapat ditambahkan ke harga dan merupakan dasar untuk perhitungan laba. Menurut Hanafi semua biaya yang diterima dari praktek komersial atau jual beli dapat ditambahkan ke harga biaya mengenai biaya perolehan dari komoditas tersebut. Menurut Hanbali dan Imam Shafi'i semua biaya aktual yang terjadi sehubungan pembelian komoditas dapat ditambahkan asalkan ada kesepakatan dengan nasabah. Menurut Maliki biaya yang dapat ditambahkan kedalam harga adalah biaya yang dikeluarkan seperti penyimpanan barang atau biaya pengangkutan, namun biaya tersebut tidak termasuk dalam keuntungan dan untuk keuntungan dapat ditambahkan lagi (Mansuri, 2006).

Selain itu penetapan margin pada murabahah menurut otoritas jasa keuangan ada beberapa point, sebagai berikut :

a. Margin jual Murabahah merupakan tingkat keuntungan yang diharapkan (expected yield) oleh lembaga keuangan syariah.

b. Margin (mark up price) ditentukan berdasarkan kesepakatan antara lembaga keuangan syariah dan Nasabah.

c. Margin dinyatakan dalam bentuk nominal atau persentase tertentu dari Harga Pokok lembaga keuangan syariah.

d. Perhitungan Margin dapat mengacu pada tingkat imbalan yang berlaku umum pada pasar keuangan dengan mempertimbangkan ekspektasi biaya dana, risk premium dan tingkat keuntungan. 
e. Margin tidak boleh bertambah sepanjang masa pembiayaan setelah kontrak disepakati dan ditandatangani kedua belah pihak.

f. Lembaga keuangan syariah dapat memberikan potongan margin Murabahah sepanjang tidak menjadi kewajiban Bank yang tertuang dalam perjanjian.

\section{Aplikasi Modern Murabahah Dan Skema Pembiayaan Murabahah}

Lembaga keuangan syariah menggunakan teknik ini untuk membiayai proyek-proyek. mereka membeli komoditas untuk kas dan kemudian menjualnya kepada nasabah dengan biaya ditambah keuntungan atas dasar pembayaran tangguhan. Di lembaga keuangan syariah murabahah dipraktekkan dengan cara berikut (Mansuri, 2006):

a. Nasabah mengajukan kepada lembaga keuangan syariah untuk melakukan permintaan pembelian terhadap barang-barang tertentu. Nasabah juga diminta untuk mendiskripsikanspesifikasi barang yang diminta.

b. Dalam hal ini lembaga keuangan syariah menyetujui permintaannya, kemudian meminta nasabah yang membeli barang tersebut membuat kesepakatan mengenai margin yang ditetapkan.

c. Setelah penandatanganan usaha untuk pembelian, lembaga keuangan syariah melakukan pembelian barang yang dibutuhkan.

d. Setelah lembaga keuangan syariah telah membeli dan mengambil kepemilikan dari mereka, itu masuk ke dalam kontrak murabahah dengan nasabah. kontrak termasuk markup atas biaya barang dan jadwal pembayaran. Lembaga keuangan syariah menyerahkan barang ke nasabah sebagai pengganti cek bearing tanggal masa sesuai dengan jadwal pembayaran.

e. Untuk menjamin pembayaran harga, lembaga keuangan syariah dapat meminta pembeli untuk memberikan keamanan dalam bentuk jaminan.

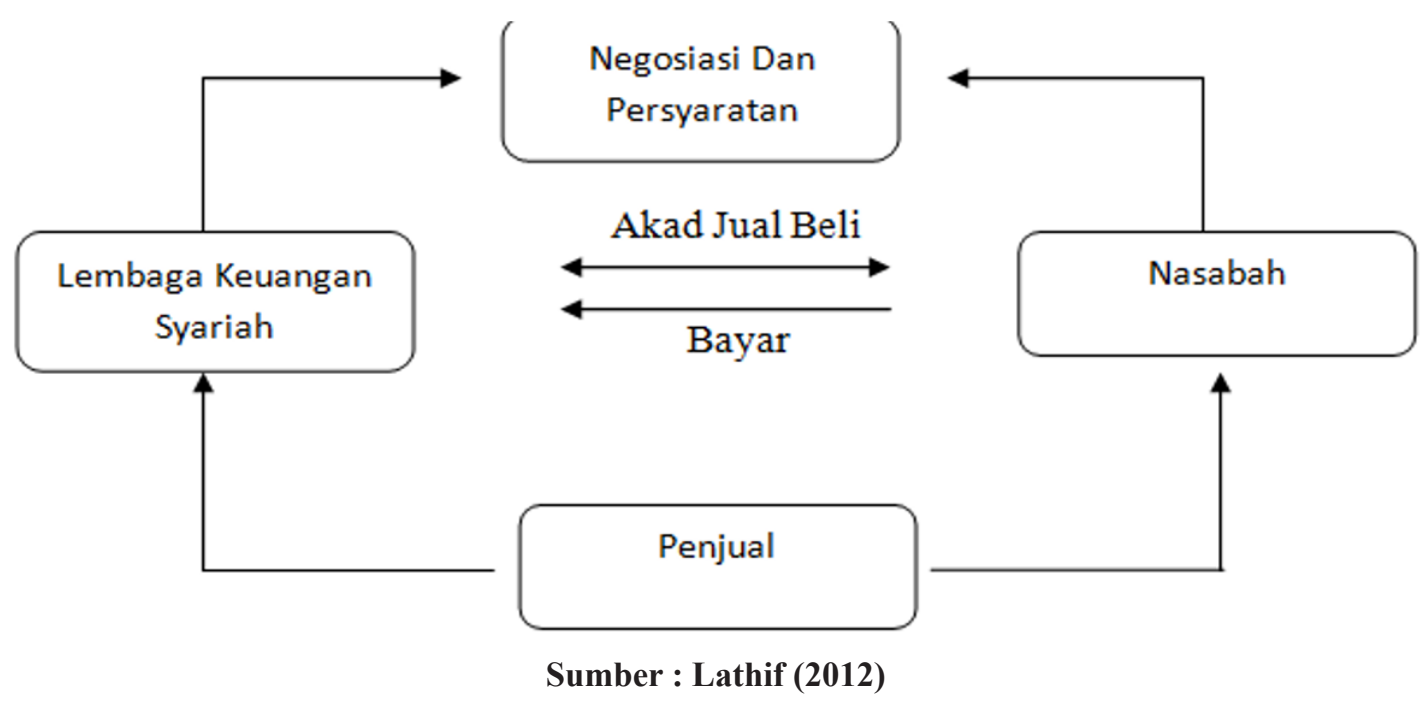

Tipe pertama penerapan murabahah adalah tipe konsisten terhadap fikih muamalah. Dalam tipe ini, lembaga keuangan syariah membeli dahulu barang yang akan dibeli oleh nasabah setelah ada perjanjian sebelumnya. Setelah barang dibeli atas nama lembaga keuangan syariah kemudian dijual ke nasabah dengan harga perolehan ditambah margin keuntungan sesuai kesepakatan. Pembelian dapat dilakukan secara tunai (cash), atau tangguh, baik berupa angsuran atau sekaligus pada waktu tertentu. Pada umumnya nasabah membayar secara tangguh. tipe kedua mirip dengan tipe yang pertama, tapi perpindahan kepemilikan langsung dari supplier kepada nasabah, sedangkan pembayaran dilakukan lembaga keuangan syariah langsung kepada penjual pertama/supplier. Nasabah selaku pembeli akhir menerima barang 
setelah sebelumnya melakukan perjanjian murabahah dengan lembaga keuangan syariah. Pembelian dapat dilakukan secara tunai (cash), atau tangguh baik berupa angsuran atau sekaligus pada waktu tertentu. Pada umumnya, nasabah membayar secara tangguh.Transaksi ini lebih dekat dengan murabahahyang asli, tapi rawan dari aspek legal (Lathif, 2012).

Contoh lain dalam skema ini untuk seorang pedagang yang hendak membeli barang dagangan melalui pembiayaan murabahah. Pedagang tersebut mengajukan permohonan kepada BMT, lalu BMT membelikan barang tersebut kepada supplier, kemudian BMT menyerahkan barang pesanan kepada pedagang dengan tingkat margin yang telah disepakati ketika akad, lalu pedagang membayar harga barang kepada BMT secara tunai maupun melalui cicilan beserta margin yang disepakati.

\section{Rukun Dan Syarat Murabahah}

Murabahah sebagai wujud dari kegiatan muamalah tentu memiliki rukun dan syarat, agar kegiatannya bisa sah menurut syariat Islam. Dibawah ini ada beberapa point mengenai rukun dan syarat pembiayaan murabahah menurut Anggadini (2008):

a. Rukun Murabahah

1) Pihak yang berakad: penjual dan pembeli

2) Objek yang diakadkan: Barang yang diperjualbelikan dan harga

3) Sighat/ Akad: Serah (Ijab) dan Terima (Qabul)

b. Syarat Murabahah

1) Pihak yang berakad:

a) Sebagai keabsahan suatu perjanjian (akad) para pihak harus cakap hukum.

b) Sukarela (ridho), tidak dalam keadaan terpaksa/ dipaksa dan tidak di bawah tekanan.

2) Obyek yang diperjualbelikan:

a) Barang yang diperjualbelikan tidak termasuk barang yang dilarang (haram), dan bermanfaat serta tidak menyembunyikan adanya cacat barang.

b) Merupakan hak milik penuh pihak yang berakad.

c) Sesuai spesifikasinya antara yang diserahkan penjual dan yang diterima pembeli.

d) Penyerahan dari penjual ke pembeli dapat dilakukan.

3) Sighat:

a) Harus jelas dan disebutkan secara spesifik (siapa) para pihak yang berakad.

b) Antara ijab qabul (serah terima) harus selaras dan transparan baik dalam spesifikasi barang (penjelasan fisik barang) maupun harga yang disepakati (memberitahu biaya modal kepada pembeli).

c) Tidak mengundang klausul yang bersifat menggantungkan keabsahan transaksi pada kejadian yang akan datang.

\section{Murabahah Sebagai Model Pembiayaan}

Pada awalnya murabahah hanya dijadikan sebagai model jual beli saja bukan pembiayaan. Model pembiayaan yang sesungguhnya menurut syariah adalah mudharabah dan musyarakah, namun ada kesulitan tersendiri dalam praktiknya. Oleh sebab itu ahli syariah kontemporer telah memungkinkan murabahah dijadikan sebagai model pembiayaan sesuai dengan kondisi tertentu. Menurut Usmani (2002) ada dua poin penting yang harus dipahami dalam hal ini :

a. Hal ini tidak boleh diabaikan pada konteks aslinya bahwa murabahah bukanlah sebuah model pembiayaan, namun murabahah dijadikan sebagai pembiayaan karena untuk menghindar dari adanya bunga dan bunga bukanlah sebuah instrumen yang ideal untuk melakukan tujuan riil ekonomi islam. Penggunannya harus dibatasi pada kasus-kasus tertentu dimana mudharabah dan musyarakah tidak lagi praktis. 
b. Hal yang penting kedua adalah pembiayaan murabahah tidak hanya mengganti bunga dengan laba atau mark-up saja, namun murabahah digunakan sebagai model keuangan oleh para ulama dengan model jual beli barang produktif atau yang dapat dijual kembali. Oleh sebab itu murabahah haruslah sesuai dan tidak boleh sama dengan pinjaman berbunga. Apabila sama maka transaksi murabahah tidak valid.

\section{Fatwa DSN MUI Terkait Pembiayaan Murabahah}

Murabahah sebagai pembiayaan tentu memiliki sebuah aturan khusus agar transaksinya tidak keluar dari syariah Islam. Aturan khusus tersebut dimuat dalam sebuah Fatwa MUI(2000) tentang ketentuan murabahah yang dapat disarikan sebagai berikut :
a. Barang yang diperjualbelikan tidak di haramkan oleh syariah Islam.
b. BMT membiayai sebagian atau keselurhan harga pembelian barang yang telah disepakati kualifikasinya.
c. BMT membelikan barang yang diperlukan nasabah atas nama BMT sendiri dan pembelian ini harus sah dan bebas riba.
d. BMT harus menyampaikan semua hal yang berkaitan dengan pembelian, misalnya jika pembelian dilakukan secara utang.
e. BMT kemudian menjual barang tersebut kepada nasabah (pemesan) dengan harga jual senilai harga beli plus keuntungannya. Dalam kaitan ini BMT harus memberitahukan secara jujur harga pokok pembelian barang berikut biaya yang diperlukan.
f. Jika BMT hendak mewakilkan kepada nasabah untuk membeli barang dari pihak ketiga, akad jual beli murabahah harus dilakukan setelah barang secara prinsip menjadi milik BMT.
g. Jika nasabah kemudian menolak membeli barang tersebut, biaya riil BMT harus dibayar dari uang muka tersebut.
h. Jaminan dalam murabahah dibolehkan, agar nasabah serius dengan pesanannya.

\section{METODE PENELITIAN}

Jenis penelitian yang digunakan dalam penelitian ini adalah exploratory research. Penelitian ini dilakukan untuk menginvestigasi penerapan praktek- praktek pembiayaan murabahah yang sesuai dengan prinsip syariah di BMT Bina Usaha Kabupaten Semarang. Metode pengumpulan data yang digunakan dalam penelitian ini adalah dengan melakukan wawancara secara mendalam (in-depth interview) dalam hal pembiayaan murabahah yang mengacu pada prinsip syariah yang ditetapkan oleh DSN MUI. Responden dalam penelitian ini adalah nasabah BMT Bina Usaha Kabupaten Semarang yang menggunakan pembiayaan murabahah untuk pembelian barang atau pembiayaan untuk modal usaha. Sebanyak sepuluh (10) orang nasabah digunakan sebagai responden dalam penelitian ini. Sementara itu untuk menjawab pertanyaan penelitian digunakan 8 pertanyaan, sebagai berikut:

1. Apakah barang dari kegiatan pembiayaan murabahah yang dilakukan oleh BMT dengan saudara halal menurut syariat Islam ?

2. Apakah BMT membiayai keseluruhan harga pembelian yang telah disepakati atau hanya membiayai sebagian?

3. Apakah BMT membelikan barang yang diperlukan saudara dengan nama BMT sendiri atau dengan menunjuk saudara untuk membeli barang sendiri ? jika menunjuk saudara apakah BMT memberikan kuasa dengan surat sebagai perwakilan untuk membeli barang ?

4. Apakah BMT memberitahukan harga sesungguhnya dari perolehan barang yang hendak dijual kepada saudara?

5. Apakah margin dari harga jual yang diberikan oleh BMT terjadi kesepakatan dengan saudara ?

6. Apakah saudara diberikan spesifikasi barang yang jelas, barang yang hendak dibeli oleh 
saudara?

7. Jika saudara membatalkan pembelian barang tersebut. Apakah BMT mengembalikan keseluruhan biaya yang telah menjadi uang muka saudara saat pengajuan pembiayaan atau seluruh uang muka menjadi milik BMT?

8. Apakah BMT meminta jaminan kepada saudara ketika hendak mengajukan pembiayaan pada BMT?

Adapun langkah-langkah yang digunakan dalam pencarian data pada penelitian ini adalah sebagai berikut:

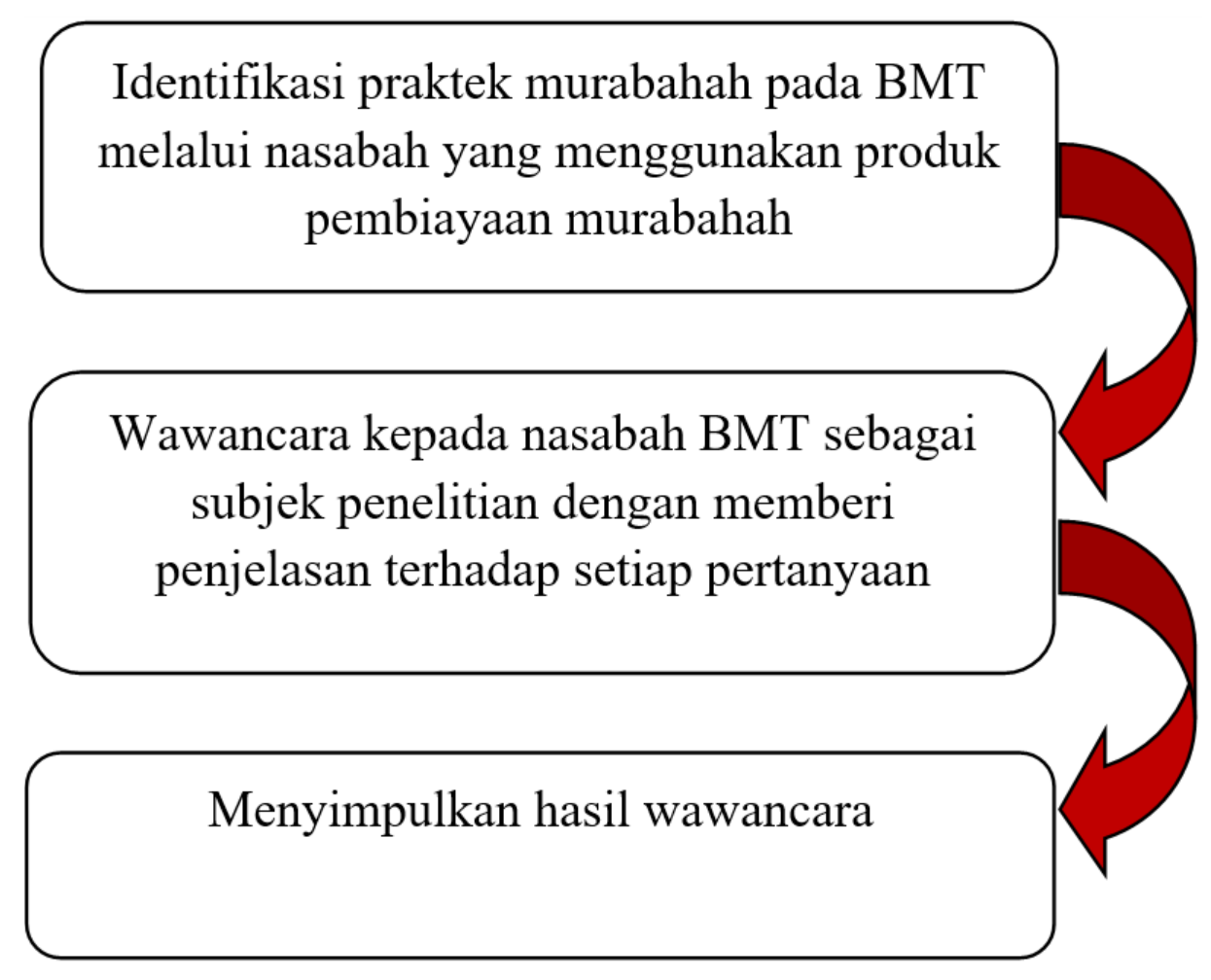

Gambar 1 : Tahapan Penelitian

\section{PEMBAHASAN}

Pada bagian ini peneliti akan menguraikan mengenai hasil wawancara dengan nasabah. Yang menjadi acuan peneliti disini dalam mencari tahu prinsip syariah yang digunakan BMT dalam pembiayaan murabahah yaitu berdasarkan pada fatwa DSN MUI tentang ketentuan pembiayaan yang telah disarikan oleh peneliti kemudian diajukan kepada nasabah BMT. Ada delapan pertanyaan penting yang peneliti ajukan kepada nasabah BMT yang peneliti telah uraikan pada bagian metode penelitian dan temuan yang didapatkan peneliti adalah sebagai berikut:

\section{Penemuan}

\section{a. Kehalalan barang yang dibiayai BMT.}

Memperoleh jawaban dari nasabah yaitu "Iya, barang yang diperual belikan ini halal sesuai syariat islam. Barang yang saya beli biasanya berupa kendaraan bermotor, TV, handphone, dan alat elektronik lainnya, kadang kalau saya mau beli motor di delaer langsung sekarang sudah tidak bisa harus melalui kredit dengan lembaga keuangan yang lai. Itu yang buat saya kadang rugi, karena bunga nya tinggi kalau saya hitung- hitung harga anguran sampai lunas itu hampir dua kali harga motor, maka dari itu saya lebih baik ambil barang lewat BMT mas lebih aman dan nyaman". 
sedangkan para pelaku usaha yang menggunakan pembiayaan murabahah salah satunya Pak Jarot 40 tahun menjawab

"ya hal tersebut halal menurut syariah Islam, biasanya pembiayaan tersebut saya gunakan untuk kulakan yang kemudian saya jual kembali pada masyarakat mas, saya menggunakan pembiayaan ini biasanya karena permintaan pembelian di warung saya tinggi, sedangkan untung saya ambil cuma dikit, jadi gak bisa tambah kulakan jadi saya ajuin pembiayaan aja ke BMT".

Jawaban responden tersebut menunjukan bahwa BMT memperjual belikan barang yang halal sesuai syariah dan nasabah juga membelikan barang yang halal sesuai syariah.

\section{Kesepakatan jumlah pembiayaan antara nasabah dengan BMT.}

"Saya ketika membeli barang berupa barang pribadi merasa bahwa BMT membiayai secara keseluruhan dan ada yang sebagian tergantung dengan uang muka yang saya miliki, kadang seperti ini mas, ketika saya punya uang sekian sedangkan anak nuntut minta belikan HP, saya lari aja ke BMT, saya punya uang segini ya sisanya biar ditambahi BMT" ujar "Bu Siti 45 tahun".

kemudian untuk para pelaku usaha yang memiliki usaha seperti pedagang pasar memberikan jawaban yaitu

"iya saya merasa terbiayai secara keseluruhan, tetapi untuk pelaku usaha seperti peternak, usaha peralatan elektronik, dan material memiliki jawaban yang berbeda dari "Pak Kasan 38 tahun" yaitu"saya merasa pembiayaan tersebut kurang cukup untuk kebutuhan modal usaha saya mas, mungkin ketersediaan dana dari BMT yang minim jadi pembiayaan yang diberikan ke saya tidak banyak".

Jawaban responden tersebut menunjukan bahwa BMT sudah membiayai secara keseluruhan untuk kegiatan jual beli. Namun untuk pembiayaan barang dagang pelaku usaha masih ada yang merasa kurang seperti pelaku usaha toko bangunan, hal tersebut juga menyesuaikan kemampuan BMT dalam membiayai.

\section{Pembelian barang oleh BMT dan surat kuasa untuk nasabah apabila membeli barang sendiri.}

"Iya saya merasa bahwa BMT membelikan barang tersebut atas nama BMT sendiri kemudian menjual kembali kepada saya, sedangkan untuk pelaku usaha mereka juga menjawab "BMT meberikan surat kuasa untuk pembelian barang yang saya butuhkan, dan BMT meminta nota pembelian sebagai barang bukti pembelian yang telah saya beli”.

Jawaban responden tersebut menunjukan bahwa untuk kegiatan jual beli, BMT membelikan barang tersebut dengan nama BMT sendiri, ketika memberikan kuasa itu hanya kepada pelaku usaha yang hendak membeli barang dagang dengan memberikan surat kuasa dan pelaku usaha tersebut wajib melampirkan noa kepada BMT. 


\section{Pemberitahuan harga perolehan barang.}

"Iya, BMT memberitahukan harga sesungguhnya dari perolehan barang yang hendak dijual kepada anggota saya, kadang juga BMT memberikan saya saran agar saya nanti gak salah beli, kalau harganya ternyata mahal dan saya tidak diberi tahu saya juga repot nantinya angsuran pokoknya takut terlalu besar".

Jawaban responden tersebut menunjukan dalam hal ini BMT telah memberitahukan harga barang perolehan kepada nasabah.

\section{Kesepakatan dalam menentukan margin.}

Menurut "Bu Jaenah 51 tahun" "Iya, pasti ada kesepakatan dalam penentuan margin dari jual beli ini. Tapi biasanya ditawarin dulu margin yang ingin diambil BMT, kadang terjadi tawar menawar dengan saya, biasanya juga berdasarkan kemampuan dari saya sebagai nasabah untuk membayar marginnya, kalau ada kesepakatan bersama kaya gini tu sama - sama menguntungkan, gak seperti yang lain yang udah ditetapkan duluan itu yang kadang bikin berat"”.

Jawaban responden tersebut menunjukan bahwa BMT menawarkan keuntungan yang hendak diambil BMT, namun BMT juga meminta kesanggupan dari nasabah hingga terjadi kesepakatan bersama. Tapi yang paling jelas kesepakatan dari keuntungan yang diambil BMT tidak merugikan BMT itu sendiri.

\section{Pemberitahuan spesifikasi barang.}

"Iya, ketika saya telah sepakat melakukan pembelian barang tersebut maka BMT memberikan spesifikasi barang yang jelas kepada saya, komplit sekali mas kala BMT kasih tau bentuk barangnya, ya mungkin karena sering melakukan kegiatan jual beli jadi pas ngasih tau spesifikasi ya jelas banget”.

Jawaban responden tersebut menunjukan bahwa dalam hal ini BMT selalu menyampaikan hal yang spesifik terkait barang yang hendak dijual tersebut.

\section{Status uang muka ketika terjadi pembatalan pembelian barang.}

"Bahwa sampai saat ini saya belum pernah melakukan pembatalan pembelian barang. Namun, diawal kesepakatan BMT sudah memberitahukan kepada saya apabila dikemudian hari ketika barang hendak dikirim kepada saya, namun saya meminta pembatalan, BMT akan mengembalikan keseluruhan biaya yang telah menjadi uang muka saya setelah dipotong dengan biaya yang telah dikeluarkan BMT dalam mendapatkan barang tersebut".

Jawaban responden tersebut menunjukan bahwa dalam hal ini BMT tidak mengambil seluruh uang muka, akan tetapi hanya biayaa riil yang dikeluarkan BMT saja. Jadi uang muka tersebut dikembalikan kepada nasabah setelah dipotong biaya. 


\section{Jaminan dalam pembiayaan murabahah.}

Menurut "Pak Daryono 44 tahun" dari salah satu responden "Iya BMT minta jaminan yang memiliki kekuatan hukum, seperti BPKB kendaraan bermotor, BPKB kendaraan mobil, dan sertifikat tanah. Kalau saya gak nyerahin jaminan saya gak bisa dapat barang yang saya inginkan dong".

Jawaban responden tersebut menunjukan bahwa BMT meminta jaminan kepada nasabah sebagai alat keseriusan nasabah dalam kegiatan ini. Kemudian BMT meminta jaminan seperti ini tak lain sebagai alternatif atau alat yang dapat di klaim apabila suatu saat terjadi sebuah risiko pembiayaan bermasalah, jadi jaminan ini bisa digunakan untuk menekan risiko yang dapat terjadi.

Diatas merupakan hasil penemuan dari penelitian ini yang dilakukan kepada sepuluh nasabah yang ada di BMT Bina Usaha. Dari hasil wawancara tersebut yaitu BMT sudah menjalankan kegiatan pembiayaan dengan mengacu pada prinsip-prinsip syariah. Dalam penemuan ini bisa diketahui mengenai proses pembiayaan terhadap nasabah. Akan tetapi yang masih menjadi hal penting khususnya para pelaku usaha merasa bahwa pembiayaan yang diberikan untuk modal usaha dirasa masih kurang cukup.

\section{KESIMPULAN}

Murabahah merupakan kegiatan jual beli antara pembeli (nasabah) dan penjual (BMT), dimana BMT membiayai keseluruhan atau sebagian barang yang akan dibeli nasabah dengan menambahkan keuntungan melalui kesepakatan antara kedua pihak dari perolehan harga barang tersebut. Isu yang berkembang terkait pembiayaan murabahah adalah menyimpang dari prinsipprinsip syariah, hasil penelitian Haitam (2015) menemukan adanya praktik murabahah yang keluar dari konteks aslinya, terutama dalam penentuan marginnya, penelitian tersebut dilakukan pada bank yang ada di indonesia.

Dalam penelitian yang dilakukan pada BMT Bina Usaha ditemukan bahwa BMT ini sudah menjalankan kegiatan pembiayaan murabahah dengan mengacu pada prinsip-prinsip syariah yang dikeluarkan oleh DSN MUI. Akan tetapi yang masih menjadi point penting khususnya para pelaku usaha merasa bahwa pembiayaan murabahah yang diberikan untuk modal usaha dirasa masih kurang maksimal, para pelaku usaha berharap bahwa pembiayaan yang diberikan bisa mencukupi agar keberlangsungan usaha dapat memberikan pencapaian yang maksimal.

Sebenarnya pemberian pembiayaan murabahah kepada pelaku usaha kurang tepat, yang menjadi pembiayaan untuk kegiatan usaha seharusnya pembiayaan mudharabah dan musyarakah. Dari diskusi singkat dengan BMT menjelaskan bahwa BMT kesulitan apabila menggunakan akad mudharabah dan musyarakah, banyak dari nasabahpun belum paham mengenai keseluruhan pembiayaan termasuk pembiayaan murabahah, mereka hanya beranggapan bahwa sistem pembiayaan di BMT lebih menguntungkan daripada sistem kredit di bank konvensional. BMT juga merasa ragu dalam menerapkan akad mudharabah dan musyarakah karena terlalu sulit dan takut menyimpang dari prinsip syariah. Oleh karena itu BMT sebaiknya harus menjaga praktik pembiayaan murabahah yang sudah berjalan sesuai dengan prinsip syariah, jangan sampai menyimpang dari ketentuan ketentuan yang ada. lebih dari itu kurang optimalnya pembiayaan yang lain harus lebih di upayakan, dengan memberikan pemahaman yang lebih luas kepada nasabah yang menjadi anggota BMT.

\section{DAFTAR PUSTAKA}

Anggadini, S. D. 2008. Penerapan Margin Pembiayaan Murabahah Pada BMT Pacet Cianjur. Fakultas Ekonomi. Unikom. Vol. 9. No. 2. Hal : 187-198Fatwa DSN MUI. 2000. Pembiayaan 
Murabahah

Haitam, Ibnu. 2015. Review Of The Theory And Practice Of Islamic Banking In Indonesia. AICIF. Vol 1. No. 1Heykal, Mohamad. 2012. Perbandingan Pembiayaan Murabahah \& Musyarakah Menurun Untuk Produk Pembiayaan Konsumtif Pada Bank Syariah. CBAM. ISSN : 2302 9791. Vol : 1. No : 1. Page : 563-572

Mansuri, M. Tahir.2006. Islamic Law Of Contracts And Business Transactions. New Delhie: Adam Publisher And Distribution

Otoritas Jasa Keuangan. 2016. Standar Produk Perbankan Syariah. http://www.ojk.go.id/id/kanal/ syariah/berita-dan-kegiatan/publikasi/Documents/Pages/Buku Standar-Produk-PerbankanSyariah-Murabahah/Buku Standar Produk Murabahah.pdf. Diunduh Desember 2016

Usmani, Taqi. 2002. An Introduction To Islamic Finance. Makataba Ma'arif Quran Karachi

Lathif, A. A. 2012. Konsep Dan Aplikasi akad murabahah pada Perbankan Syariah Di Indonesia. MES. Jakarta. Ahkam: Vol. XII, No. 2. Hal 69-78. 